\title{
E-commerce Technology in Agricultural World
}

\author{
Rahma Wahdiniwaty ${ }^{1}$,Gerial Giovani Esertha ${ }^{2}$ \\ \{rahma@unikom.ac.id ${ }^{1}$, gerialgiovanni@mahasiswa.unikom.ac.id ${ }^{2}$ \} \\ Departemen Magister Manajemen, Universitas Komputer Indonesia, Indonesia ${ }^{1}$, \\ Fakultas Teknik dan Ilmu Komputer, Universitas Komputer Indonesia, Indonesia ${ }^{2}$
}

\begin{abstract}
The purpose of this study is to develop the agricultural business by using ecommerce technology, the benefits of e-commerce applications to facilitate business in agriculture. The method used in this study is descriptive, to present a complete business related to the agricultural world under study. The design results of e-commerce technology in the world of agriculture are to identify seeds, plants and medicinal plants needed for farmers to improve the quality of superior agriculture. This e-commerce design discusses the system of payment transactions, sales, and orders made by users using the e-commerce technology system. With the existence of an e-commerce system this is very influential for business people in the world of agriculture.
\end{abstract}

Keywords : Power Electronics, Multilevel Inverter, Single-Phase Inverter, PWM, SPWM.

\section{Introduction}

E-commerce business world is an online transaction process that is familiar to the international community for both developed and developing countries. E-commerce is an activity carried out online in transacting businesses that are exchanged with sellers and buyers. Activities in online shopping using the internet and making payment transactions through digital money transfers are a new way to connect their businesses and overcome increasingly fierce competition that is more effective and efficient [1]. Every person who has electronic devices and has access to the internet network can participate in e-commerce activities. For business people, e-commerce is very useful to launch their business. Businessmen are very easy to do buying and selling activities, easy to communicate for product details offered by producers, as well as payment methods that are not difficult and fast [2]. The product is something that can be offered to the market and can meet consumer needs. Consumer satisfaction does not only apply to physical products, but satisfaction is obtained from the purchase of products. This satisfaction is caused by the accumulation of physical, psychological, symbolic, and service provided by the producer [3]. Good accessibility can make it easy for consumers to order ecommerce products offered by the company. Factors that must be considered to provide good accessibility services in product delivery to consumers are factors of ease of access, road quality, parking facilities, and driving time [4].

Muller explains and understands the agricultural e-commerce market; we develop entrepreneurs as bodies in imbalances. Entrepreneurs have a long and varied history in economic theory but implementation in the economic field is not attractive. In his discussion of the concept, Rosen said that entrepreneurs have no status in contemporary economic theory and he 
added that mistakes are one theory, not fact [5]. Farmers are open to adopting information technology, even if they do more than all or other industries.

Wahdiniwaty also explained that to develop an agro-based e-commerce business, things that need to be considered are product quality, price and reference groups to provide informative, normative influences and value expressions of the products offered [6].

A very relevant observation comes from adoption technology which helps manage finance or the environment. National annual USDA The Study of Agricultural Resource Management shows 29 percent of farmers had internet access in 1999 and about 15 percent of what was done some businesses over the Internet, mostly to purchase crop inputs [7]. While agriculture contributes less $4 \%$ of South Africa's gross domestic product (GDP), provides around $10 \%$ of formal state sector employment opportunities. The relative agricultural sector the influence of great relations with other parts of the economy, and is a major foreign producer in exchange. Currently, more than $20 \%$ of exports of non-gold merchandise in the country primary agricultural products. A common example is the wine, fruit and life supply industries [8]. The history of the open electronic market in agriculture, although relatively long, has yet to provide significant hope for those who might believe the market is a panacea for producers and the same buyer. Like other market mechanisms, testing its relevance and usefulness will ultimately be reflected in the choice of market participants and will depend on choice

company and company associations in structuring and organizing agricultural exchanges and markets for the internet [9]. According to survey respondents, most agricultural input companies use the Internet in their business operations. Without a website, more than half were planned to develop a site in 2001. Most of the remaining companies plan to develop the website but have not set a specific time for development [10].

Agriculture is the nature of business associated with agro-based industries for business, namely those that aim to make a profit - overall operations related to efforts to produce agriculture, for processing and marketing [11]. Internet-based e-commerce is not including organizations that only manage websites that display information on the products they sell in the physical world [12].

The purpose of this study is to identify business developments in the world of agriculture by using e-commerce technology and the benefits of online technology for businessmen in agriculture. The method used in this study is descriptive, to present a complete business related to the agricultural world under study.

\section{Material and Method}

This research used descriptive methods to determine the variables associated with ecommerce and business in the world of agriculture and using designs that the authors made related to online marketing so that it could analyze how much influence e-commerce technology has in the world of agricultural business.

\section{Results and Discussion}

To get customers to access site pages in the world of online agricultural business, sellers can upload and explain the products offered. For example, for online businesses that offer 
insecticide sprinklers, plant seeds, tractors to plow fields and pest control products. The payment method used is direct and indirect. For example, buyers of indirect transactions order payment products using money transfer transactions through bank account numbers and direct transaction buyers can directly come to the store. Ordering can be done easily anytime and anywhere users need it as well as producers regardless of the wishes of buyers, who can access through browsing the internet on various electronic devices or personal computers (see Figure 1).

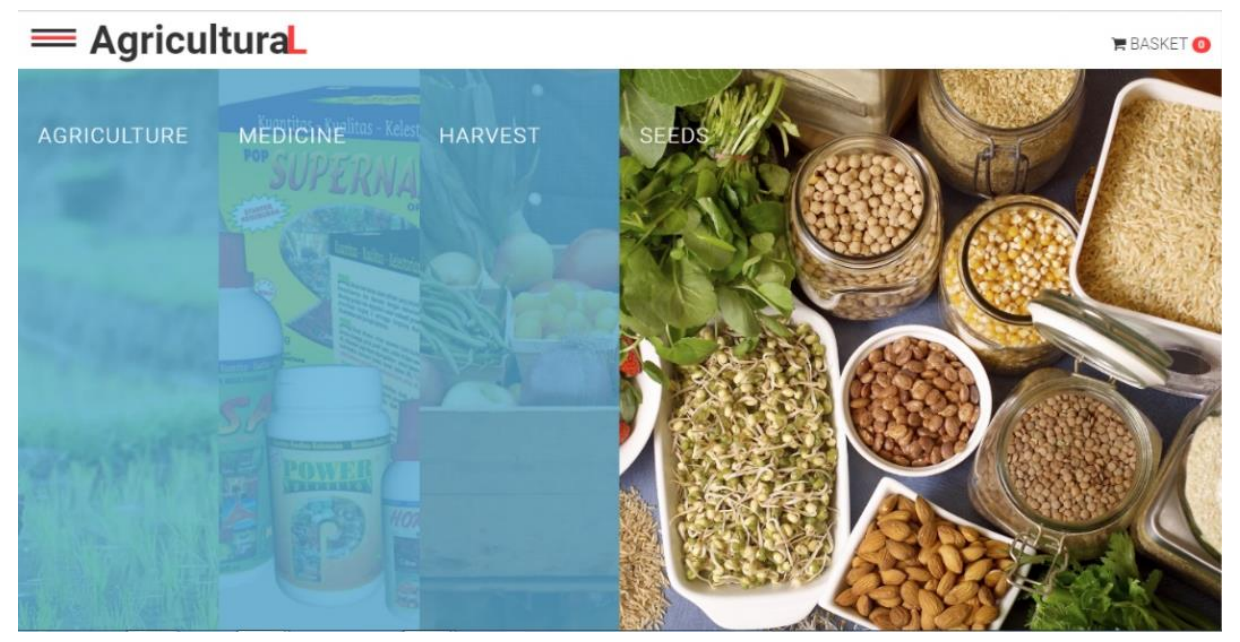

Fig 1. Home Menu.

In the main view, there are menu and submenu sections. So sellers and buyers can create and use accounts. For example, the account for admin/seller is used to upload the latest product to be marketed and for the buyer's account as a member of the site in order to get the latest product notifications and get order history. There are several products available on this site. In this study, the authors developed a product information technology system from this online business (see Figure 2).

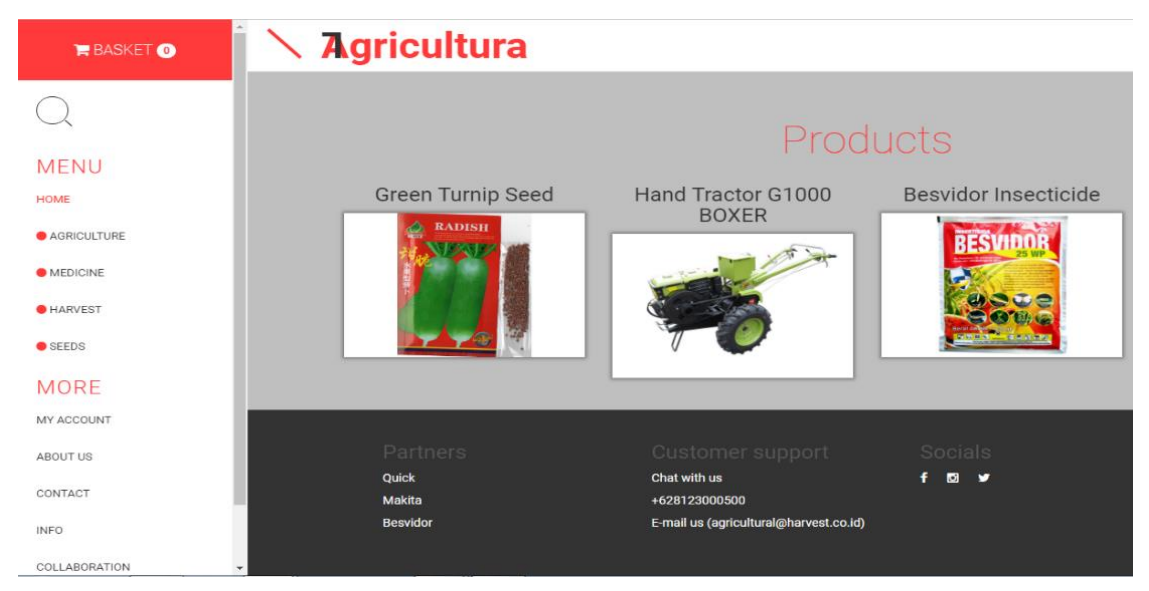

Fig 2. Products Menu. This figure was adopted on November 18, 2018. 
In the shopping cart menu, users can fill in the data in the section that has been provided to order the product to be purchased. For example, choosing a payment method through the bank account listed, filling in the address, email, telephone number, how many products will be ordered and selected shipping method. Existing products in the agricultural shop are local and imported products, the products contained are listed in terms of prices and product names and can change if indeed the product experiences a price increase (see Figure 3).

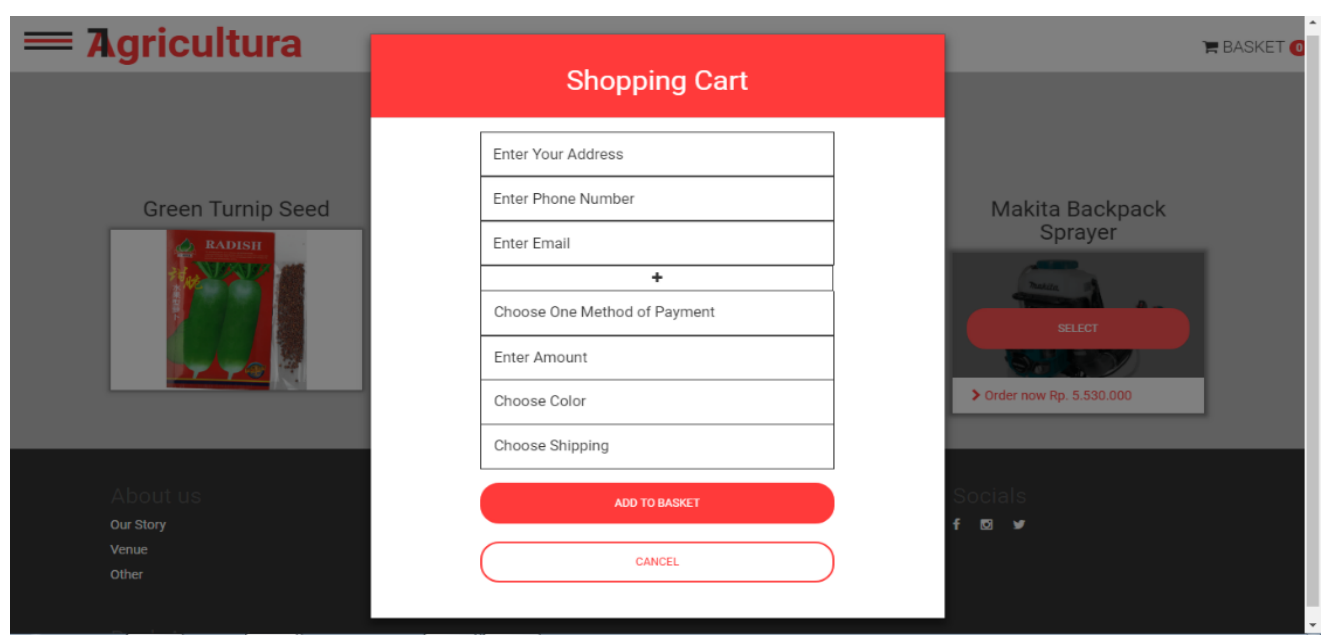

Fig 3. Shopping Cart. This figure was adopted on November 182018.

After the buyer fills in the desired order data, the buyer goes directly to the order checkout form after clicking add to basket on the shopping cart form. This view, there is information about product descriptions, brands, and prices of goods ordered, taxes, shipping costs using JNE (Regular) services according to the input chosen by the buyer, as well as the total order. This view informs the buyer about the type of product or product specifications so that the buyer knows the item that has been ordered (see Figure 4).

\section{Checkout Order

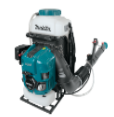

Makita Backpack Sprayer

The best sprayer in the world agriculture. $75,6 \mathrm{cc} 4$ Stroke Mist Blower Type: PM7650H.
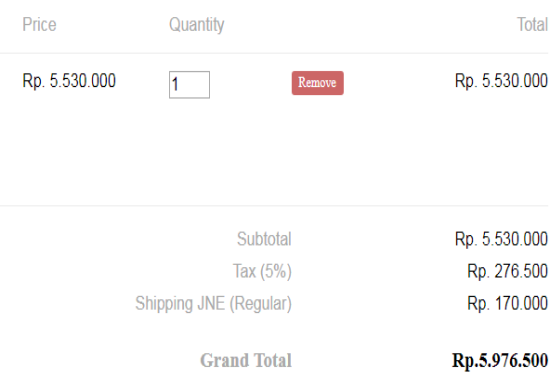

Fig 4. Checkout Order. This figure was adopted on November 182018. 
In this online agricultural business payment form, the buyer chooses a transfer method to store account and manufacturer will send bank account number to the email address that the buyer has filled in previous form. If buyer has not made a transfer within 5 hours of order process to the store account, the order will not be processed or canceled. The method payment that will be done will certainly be guaranteed security. If buyer has made a payment, do not forget to click the payment confirmation button and make sure all data has been filled in correctly, if, within $2 \times 24$ hours after order confirmation is still not processed by store, buyer is expected to show proof of transfer to admin agriculture shop (see Figure 5).

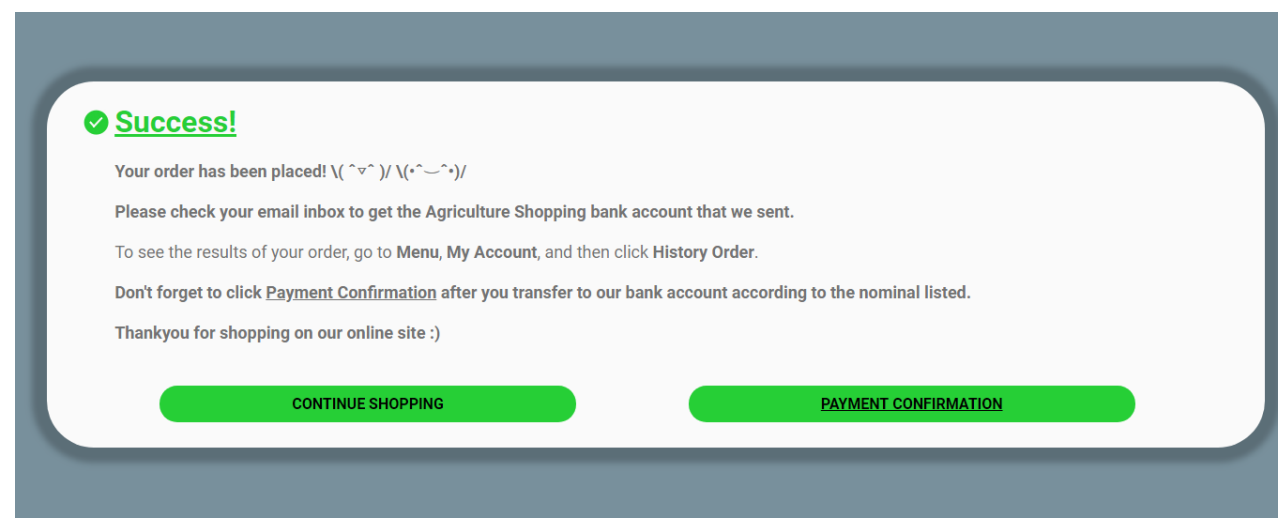

Fig 5. Payment Form. This figure was adopted on November 182018.

After all data and payment methods are done, the buyer waits for the arrival of the item according to the time set when choosing the shipping method. Non-refundable money. Conditions that can be returned or exchange of goods if product has reached the buyer in a damaged condition or cannot be used properly.

\section{Conclusion}

With the development of technology, is very easy for the community especially in business and increased satisfaction levels for people who do online shopping activities, no need to go out of the house to buy the desired item. You only need to sit relaxed at home while holding a cellphone that is accessed by the internet or using a personal computer connected to the internet so that you can shop online quick and easy. E-commerce technology, consumers have the convenience and do not have to worry about payment through the transfer method if the chosen store is trusted.

\section{References}

[1] Kardaras, D., \& Papathanassiou, E. : The development of B2C e-commerce in Greece: current situation and future potential. Internet Research, 10(4), 284-294 (2000).

[2] Okunbor, D. : E-Commerce Solutions At Higher Education Institutions: A New Perspective. Review Of Business \& Technology Research (Rbtr) 3, No 1, 2010, 547 (2010). 
[3] Soegoto, E. S. : Entrepreneurship Menjadi Pebisnis Ulung Edisi Revisi. Elex Media Komputindo, 7, No 7, 2014, 515 (2014).

[4] Wahdiniwaty, R. : Aksesibilitas Wisata Pada Kota Metropolitan di Negara Berkembang. Majalah Ilmiah Unikom, 11(02), 200-209 (2016).

[5] Mueller, R. A. : E-commerce and entrepreneurship in agricultural markets. American Journal of Agricultural Economics, 14 no. 9 pp. 1243-1249 (2014).

[6] Wahdiniwaty, R., \& Wijayanti, U. Pengaruh Kelompok Acuan, Kualitas Produk Dan Harga Terhadap Keputusan Pembelian Tas Exsport Pada Pt. Eksonindo Multi Product Industry di Bandung. Jurnal Ilmiah Magister Manajemen, 5 (3),pp. 95-112(2016).

[7] Ehmke, C., Ernst, S., Hopkins, J., \& Tweeten, L. : The market for e-commerce services in agriculture. In Select Paper for Agricultural and Applied Economics Association (AAEA) Annual Meetings, Chicago, Illinois. 54 (3), (pp. 55-69) (2001).

[8] Cloete, E., \& Doens, M. : B2B e-marketplace adoption in South African agriculture. Information Technology for Development, 14(3), 184-196 (2008).

[9] Wheatley, W. P., Buhr, B., \& DiPietre, D. : E-Commerce in agriculture: development, strategy, and market implications (No. 13938). University of Minnesota, Department of Applied Economics. 33 (2), (pp. 145-166) ( 2001).

[10] Henderson, J., Dooley, F., \& Akridge, J. Internet and e-commerce adoption by agricultural input firms. Review of Agricultural Economics, 26(4), 505-520 (2004).

[11] Mufti, A., Novianti, D., \& Anjani, D. : Analisis perancangan sistem e-commerce untuk jual beli hasil pertanian berupa beras. SEMNASTEKNOMEDIA ONLINE, 5(1), 2-3 (2017).

[12] Mahadevan, B. : Business models for Internet-based e-commerce: An anatomy. California management review, 42(4), 55-69 (2000). 